\title{
PENGEMBANGAN STANDARISASI PEWARNA ALAMI BATIK DARI KULIT KAYU SECANG (Caesalpinia sappan L.) DENGAN TEKNIK SPEKTROSKOPI
}

\section{(THE DEVELOPMENT OF STANDARDIZATION NATURAL COLOUR FROM BATIK OF STEAM BARK (Caesalpinia sappan L) BY SPECTROSCOPHY METHOD)}

\author{
Arum Restu Widyasti, Astuti Lestari, Khoirul Amri, Fakhrizal Naufal, dan Kun Sri Budiasih \\ Fakultas Matematika dan Ilmu Pengetahuan Alam Universitas Negeri Yogyakarta \\ J1. Colombo No. 1 Yogyakarta 55281 \\ e-mail: aroemrestu@gmail.com
}

\begin{abstract}
Abstrak
Tujuan dari penelitian ini adalah diperoleh suatu metode standarisasi warna yaitu penilaian secara konsisten terhadap warna yang dibentuk oleh pewarna alami secang, sehingga dapat dijadikan acuan warna zat pewarna alami batik yang dibuat. Tahapan standarisasi pewarna alami dimulai dengan pemeriksaan taksonomi/determinasi, preparasi pewarna secang dengan cara ekstraksi, proses standarisasi yang meliputi proses standarisasi pewarna alami dan pembuatan standar pewarna sintetis sebagai pembanding, penetapan standar warna, aplikasi zat warna terstandar pada proses pembatikan meliputi pembuatan pola batik dan pembatikan dengan lilin/malam dan proses pewarnaan batik dengan pewarna secang. Analisis data dilakukan secara kualitatif dan kuantitatif terhadap data absorbansi dan panjang gelombang yang diperoleh dari warna merah yang dibentuk oleh pewarna secang. Hasil penelitian menunjukkan bahwa panjang gelombang serapan maksimum standar warna merah diperoleh pada 450,20 $\mathrm{nm}$. Panjang gelombang inilah yang digunakan sebagai standar pengukuran warna merah secang yang diterapkan.
\end{abstract}

Kata kunci: metode spektoskopi, pewarna alami secang, standarisasi pewarna alami

\begin{abstract}
The purpose of this research is to obtain a method of color standardization which is a consistent assessment of the color formed by secang natural dye, so it can be used as a reference color of natural dyes of batik.Standardization steps of natural dyes included taxonomic examination, preparation of secang dye by extraction, standardization process by spectroscopic measurement, with "rapid" dye as standard, application on batik process including batik pattern making and wax application on batik and batik coloring process with secang dye. Data was analized by absorbance vs wavelength obtained from red color formed by secang dye. The results showed that the maximum absorption wavelength of the standard red color was obtained at $450.20 \mathrm{~nm}$. This value is used as the standard red color measurement.
\end{abstract}

Keywords: Caesalpinia sappan L., natural dye, spectroscopy method, standardization 


\section{PENDAHULUAN}

Terdapat dua macam pewarna pada batik, yaitu pewarna sintetis dan alami. Pada pewarna sintetis, warna yang ditimbulkan sangat menarik, konsisten dan terstandar, tetapi harganya mahal dan sangat berbahaya bagi lingkungan. Sementara pada pewarna alami warna yang ditimbulkan kurang menarik, tidak konsisten dan tidak terstandar,tetapi mudah didapat, harga murah, dan ramah lingkungan (Imam, 2003). Dalam industri batik diperlukan suatu pewarna batik yang menarik, konsisten, terstandar, harga terjangkau dan ramah lingkungan.

Pembuatan bahan pewarna alami merupakan alternatif pewarnaan kain untuk mengurangi risiko polusi limbah dari pewarna sintetis. Sebagian besar pewarna alami dibuat dengan cara ekstraksi bahan hayati seperti bagian tumbuhan.Kelemahan aplikasi pewarna alami adalah hasil warna yang tidak konsisten dan tidak terstandar. Akibatnya warna yang dikehendaki oleh pemakai tidak selalu dapat dicapai dengan konsisten. Hal ini tidak menguntungkan bagi pengrajin tekstil/batik karena tidak dapat menghasilkan produk yang seragam.

Salah satu bidang yang memerlukan suatu metode standarisasi warna adalah industri batik. Hal itu menjadi sangat penting agar dapat dihasilkan batik dengan kualitas yang baik dan warna batik yang konsisten. Warna merupakan faktor penting yang pertama kali dilihat konsumen (Winarti, 2005). Warna yang tidak konsisten dapat disebabkan karena bahan baku yang tidak terstandar, seperti asal tanaman yang dipakai, usia tanaman, bagian tanaman yang dipakai dan konsentrasi bagian aktif yang dibuat. Oleh karena itu, dibutuhkan suatu metode standarisasi agar diperoleh suatu warna yang konsisten (Amin \& Yuliana, 2016).

Salah satu cara yang dapat digunakan untuk menciptakan pewarna alami batik dengan kriteria warna yang konsisten adalah dengan melakukan suatu standarisasi terhadap pewarna alami yang telah ada dengan teknik spektroskopi. Teknik ini didasarkan pada interaksi cahaya dengan atom dan molekul. Salah satu metode spektroskopi adalah spektroskopi UV-Vis, yaitu metode analisis spektroskopi yang memanfaatkan karakterisitik cahaya pada panjang gelombang UV-Visible (ultra violet-tampak) yaitu panjang gelombang antara 400-780 $\mathrm{nm}$. Metode ini membandingkan intensitas warna larutan dalam berbagai konsentrasi yang akan terukur oleh alat spektrofotometer $\mathrm{Uv}$-Vis. Interaksi antara materi (partikel zat tersebut) dengan energi (sinar UV-Vis) direkam dalam bentuk parameter absorbansi (serapan) (Amin $\&$ Yuliana, 2016). Metode ini dapat mengukur dengan teliti suatu larutan berwana tertentu yang akan menunjukkan sinyal serapan maksimal pada panjang gelombang tertentu pula. Dengan metode ini dapat diperoleh 
pengukuran secara konsisten terhadap warna yang dibentuk oleh suatu zat pewarna. Dengan demikian zat warna alami dapat diukur secara konsisten dengan metode ini.

Sampel dalam penelitian ini adalah tanaman secang (Caesalpinia sappan L.), yang memberikan warna merah. Warna merah ditimbulkan oleh zat warna brazilin (Fardhyanti \& Riski, 2015). Konsistensi warna merah dari tanaman secang diperlukan untuk membuat warna produk yang seragam dan konsisten. Tanaman ini juga dapat tumbuh dimana saja dan akan dapat digunakan secara konsisten jika warna yang dihasilkan distandarisasi. Penerapan zat warna secang yang telah distandarisasi dilakukan pada kain katun primisima yang biasa dipakai dalam pembuatan batik secara tradisional. Penerapan pada jenis kain lainnya tidak termasuk dalam penelitian ini. Akan tetapi, zat warna standar yang telah diperoleh dapat digunakan untuk jenis kain lainnya. Tujuan dari penelitian ini adalah untuk mengembangkan metode standarisasi warna tekstil dari pewarna alami secang dengan metode spektroskopi UvVis. Metode ini menghasilkan konsistensi warna dan produk pewarna alami yang terstandarisasi dari secang.

\section{METODE PENELITIAN}

Penelitian dilakukan di Laboratorium Kimia Universitas Negeri Yogyakarta dan Laboratorium Sistematika Tumbuhan
Fakultas Biologi Universitas Gadjah Mada. Alat-alat yang diperlukan dalam penelitian ini meliputi spektrofotometer UV-Vis Shimadzu, neraca analitik, alat-alat gelas laboratorium dan perlengkapan persiapan bahan baku. Bahan yang digunakan adalah kulit kayu secang, pewarna sintetis rapid sebagai pembanding, $\mathrm{NaOH}$ (soda kaustik), akuades, kain katun primisima, dan tawas.

Penelitian diawali denganpemeriksaan taksonomi tumbuhan yang dilakukan di Laboratorium Sistematika Tumbuhan Fakultas Biologi UGM dengan membandingkan kenampakan daun dan batang secang dengan data yang terdapat di laboratorium. Ada dua macam sampel secang yang digunakan, yaitu secang yang diambil langsung dari pohon (kode A) dan secang yang dibeli dari Pasar Godean Sleman (kode B). Potongan kayu secang disortasi untuk memisahkan dari bagian-bagian yang tidak digunakan kemudian dikeringkan dengan cara diangin-anginkan. Secang dihaluskan untuk memperoleh serbuk halus simplisia. Preparasi secang dilakukan dengan cara ekstraksi terhadap simplisia secang A dan B. Serbuk simplisia kayu secang A dan B diekstraksi dengan dua cara. Cara pertama dengan direndam dalam pelarut air mendidih selama 1x24 jam dan 2x24 jam. Cara kedua dengan dididihkan bersama air selama 5 menit dilanjutkan perendaman selama 1x24 jam dan 2x24 jam. Perbandingan 
jumlah simplisia secang dan akuades yang digunakan adalah 1:6. Proses ekstraksi dilakukan secara duplo.

Proses standarisaisi meliputi pembuatan standar pewarna sintetis sebagai pembanding dan proses standarisasi pewarna alami. Pewarna sintetis diperoleh dengan membuat larutan standar rapid konsentrasi 10; 20; 30; 40; 50; 60; 70; 80; 90; dan 100 ppm. Sedangkan pewarna alami diperoleh dari ekstrak secang yang diencerkan 10 kali. Proses standarisasi tersebut dilakukan dengan mengukur panjang gelombang serapan maksimum $\left(\lambda_{\text {maks }}\right)$ ekstrak secang pada spektrometer UV-Vis merk Shimadzu. Penetapan standar warna dilakukan dengan menghitung absorbansi versus konsentrasi, menentukan hubungan antara warna dan konsentrasi, dan membuat standar nomor warna versus absorbansi. Zat warna yang telah distandarisasi diaplikasikan pada proses pembatikan. Prosesnya meliputi pembuatan pola batik, pembatikan dengan lilin/malam dan proses pewarnaan batik dengan pewarna secang. Rancangan percobaan yang akan dilakukan terdapat pada Tabel 1.

\section{HASIL DAN PEMBAHASAN}

Tanaman secang (Caesalpinia sappan L.) yang diperiksa sebagai sampel uji diperoleh dari daerah Kulonprogo.Sebelum digunakan kayu secang dideterminasi di Laboratorium

Tabel 1

Rancangan Percobaan

\begin{tabular}{|c|c|c|c|c|}
\hline No & Sumber & Cara ekstraksi & Waktu & Keterangan \\
\hline 1. & $\mathrm{~A}($ pohon $)$ & Cara 1(rendam) & $1 \times 24 \mathrm{jam}$ & Kode A1.11 dan A1.12 \\
\hline 2. & & & $1 \times 24$ jam & \\
\hline 3. & & & $2 \times 24$ jam & Kode A1.21 dan A1.22 \\
\hline 4. & & & $2 \times 24 \mathrm{jam}$ & \\
\hline 5. & & Cara 2 (direbus) & $1 \times 24$ jam & Kode A2.11dan A2.12 \\
\hline 6. & & & $1 \times 24 \mathrm{jam}$ & \\
\hline 7. & & & $2 \times 24$ jam & Kode A2.21 dan A2.22 \\
\hline 8. & & & $2 \times 24$ jam & \\
\hline 9. & $\mathrm{~B}$ (pasar) & Cara 1 (rendam) & $1 \mathrm{X} 24 \mathrm{jam}$ & Kode B1.11 dan B1.12 \\
\hline 10. & & & $1 \times 24$ jam & \\
\hline 11. & & & $2 \times 24$ jam & Kode B1.21 dan B1.22 \\
\hline 12. & & & $2 \times 24$ jam & \\
\hline 13. & & Cara 2 (direbus) & $1 \times 24$ jam & Kode B2.11 dan B2.12 \\
\hline 14. & & & $1 \times 24 \mathrm{jam}$ & \\
\hline 15. & & & $2 \times 24 \mathrm{jam}$ & Kode B2.21 dan B2.22 \\
\hline 16. & & & $2 \times 24$ jam & \\
\hline
\end{tabular}


Sistematika Tumbuhan Fakultas Biologi Universitas Gadjah Mada untuk memastikan identitas tumbuhan berdasarkan ciri fisiologis tumbuhan tersebut. Hasil determinasi menyatakan bahwa tanaman secang yang digunakan sebagai sampel berasal dari divisi Magnoliophyta, kelas Magnoliopsida, sub kelas Rosidae, bangsa Fabales, famili Caesalpiniaceae, spesies Caesalpinia sappan $\mathrm{L}$.

Ekstraksi secang dilakukan dengan menggunakan perbandingan kayu secang dan akuades 1:6 (b/v). Ekstraksi dilakukan secara duplo. Pada perendaman selama $1 \times 24$ jam dan 2x24 jam diperoleh ekstrak secang masing-masing sebanyak 8 sampel sehingga total sampel adalah 16 sampel. Hasil ekstrak secang terdapat pada Gambar 1 dan 2.
Dari 10 variasi konsentrasi larutan standar rapid yang telah dibuat, diambil 2 larutan untuk diukur panjang gelombang pada absorbansi maksimum dengan spektrometer UV-Vis. Konsentrasi larutan standar warna yang dipilih adalah $60 \mathrm{ppm}$. Gambar 3 merupakan gambar panjang gelombang yang menghasilkan absorbansi maksimum dari larutan standar tersebut.

Gambar 3 menunjukkan bahwa panjang gelombang absorbansi maksimum larutan standar pewarna rapid $60 \mathrm{ppm}$ adalah 513,2 $\mathrm{nm}$. Panjang gelombang tersebut digunakan untuk mengukur absorbansi semua variasi konsentrasi larutan standar rapid. Hasil absorbansi larutan standar rapid variasi konsentrasi 10;20; 30; 40; 50; 60; 70; 80;

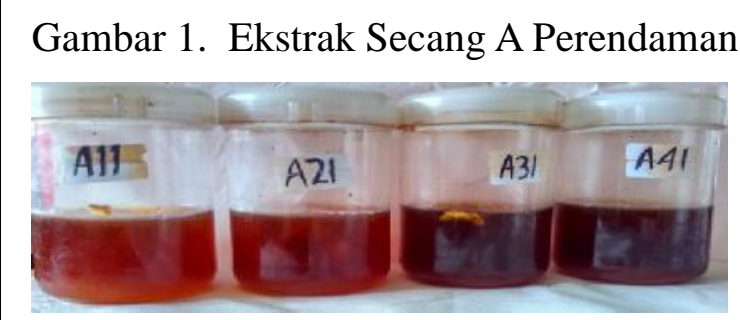

(a)

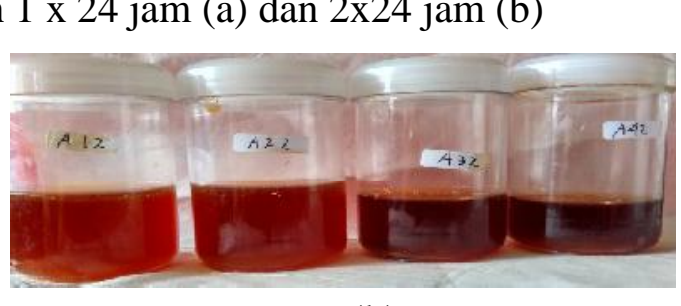

(b)

Gambar 2. Ekstrak Secang B Perendaman 1 x 24 jam

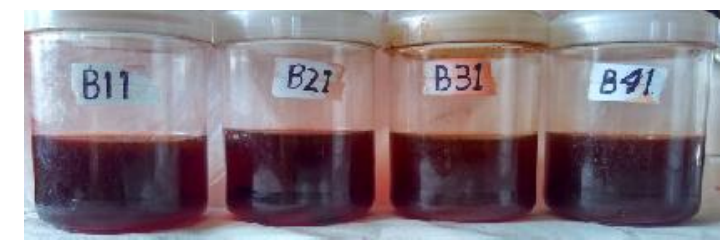

(a)

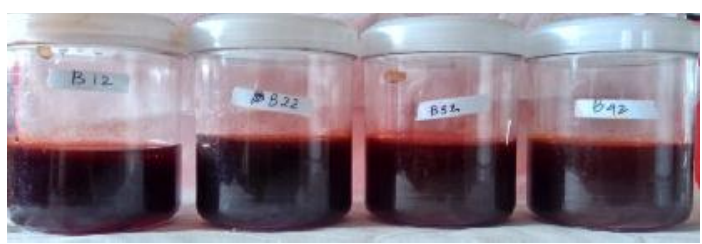

(b) 
Gambar 3. Panjang Gelombang Maksimum Larutan Standar Rapid pada 60 ppm

Data Set 60 ppm.spc - RawData

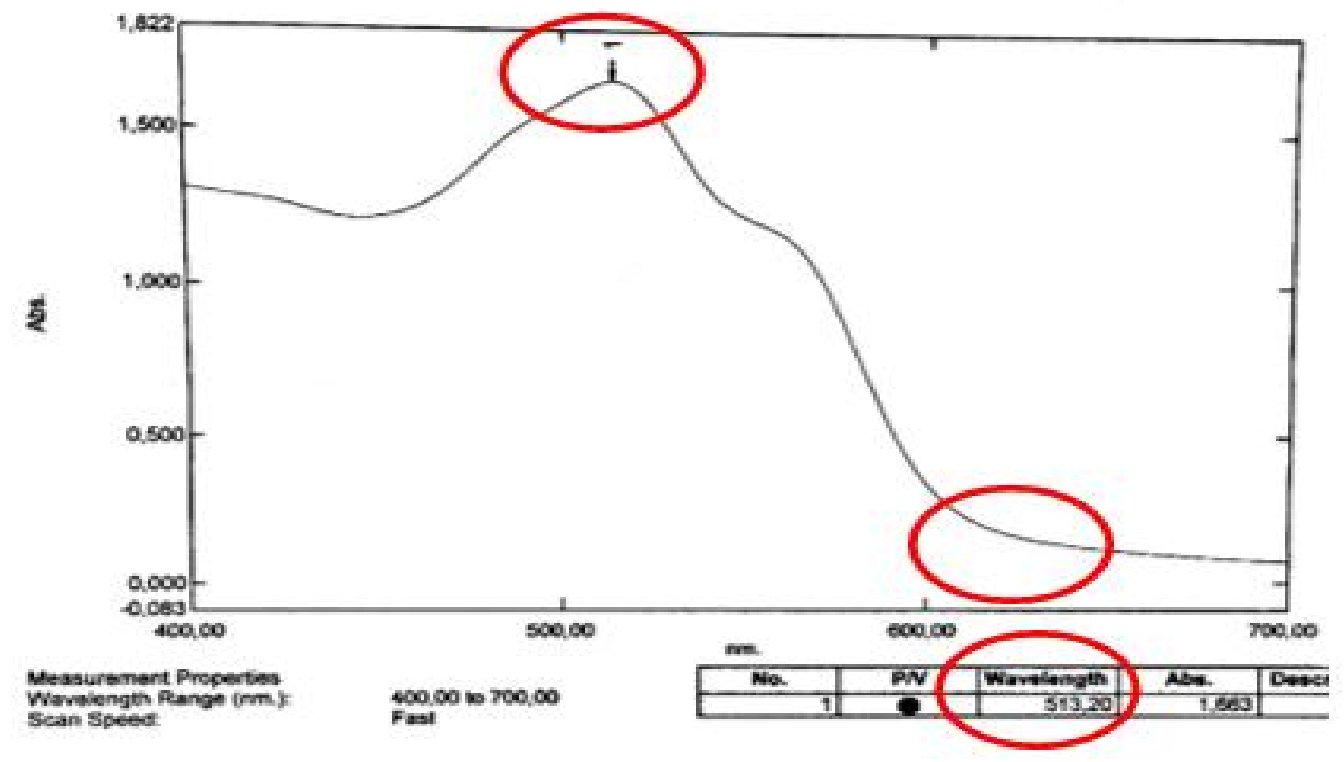

90 dan 100 ppm yang diukur pada panjang gelombang 513,6 $\mathrm{nm}$ dan 513,2 $\mathrm{nm}$ dapat dilihat pada Gambar 4.

Gambar 4 merupakan kurva standar serapan dari larutan standar pewarna sintetis rapid yang biasa digunakan sebagai pewarna kain, menunjukkan hasil pengukuran absorbansi variasi konsentrasi rapid pada panjang gelombang maksimum 513,2 nm. Serapan maksimum dari pewarna alami secang juga diukur pada panjang gelombang yang sama. Hasilnya disajikan pada Gambar 5.

Dari Gambar 5 dapat diketahui bahwa panjang gelombang serapan maksimum untuk sampel warna merah alami secang adalah 450,20 nm. Panjang gelombang serapan maksimum ini dapat dijadikan standar yang menjadi acuan konsentrasi pewarna secang yang dibuat. Serapan yang sama pada panjang gelombang yang sama menunjukkan konsentrasi yang sama dari molekul zat warna yang dibuat. Untuk selanjutnya pengukuran konsentrasi zat warna alami secang dilakukan pada panjang gelombang yang telah ditentukan dalam tahap optimasi ini sesuai kadar warna yang dikehendaki.

Gambar 6 menunjukkan grafik serapan dari kelompok A terlihat stabil sementara grafik kelompok B tidak konsisten. Hal ini berarti bahwa pewarna secang yang diambil langsung dari pohon menunjukkan warna yang konsisten. Absorbansi cara ekstraksi 
Gambar 4. Grafik Absorbansi vs Konsentrasi Pewarna Standar Rapid $\left(\lambda_{\text {maks }}\right)$

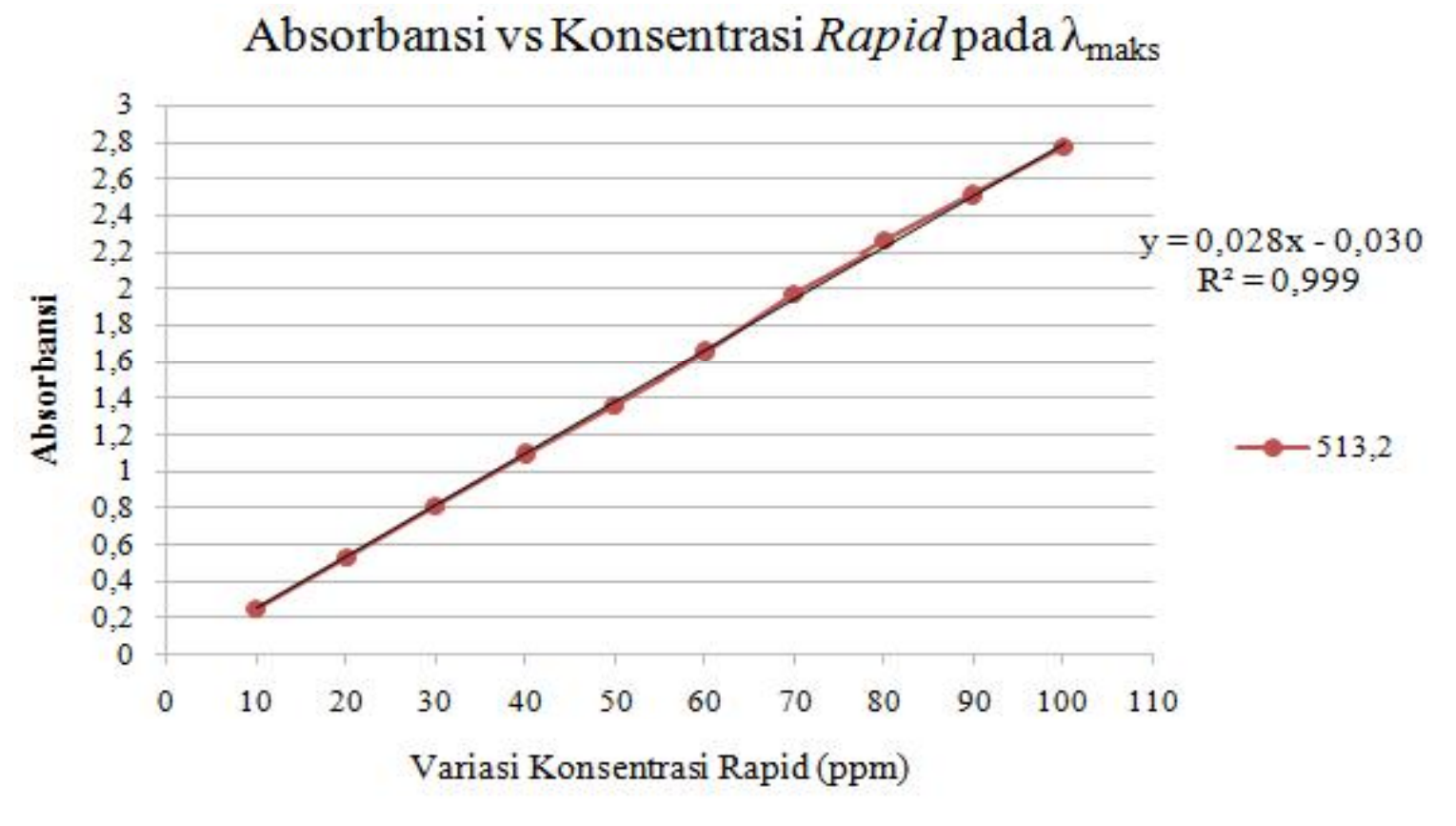

Gambar 5. Hasil Optimasi Panjang Gelombang Serapan Maksimum Pewarna Secang $\left(\lambda_{\text {maks }} 450,20 \mathrm{~nm}\right)$

Data Set: 4A1.spc - RawData

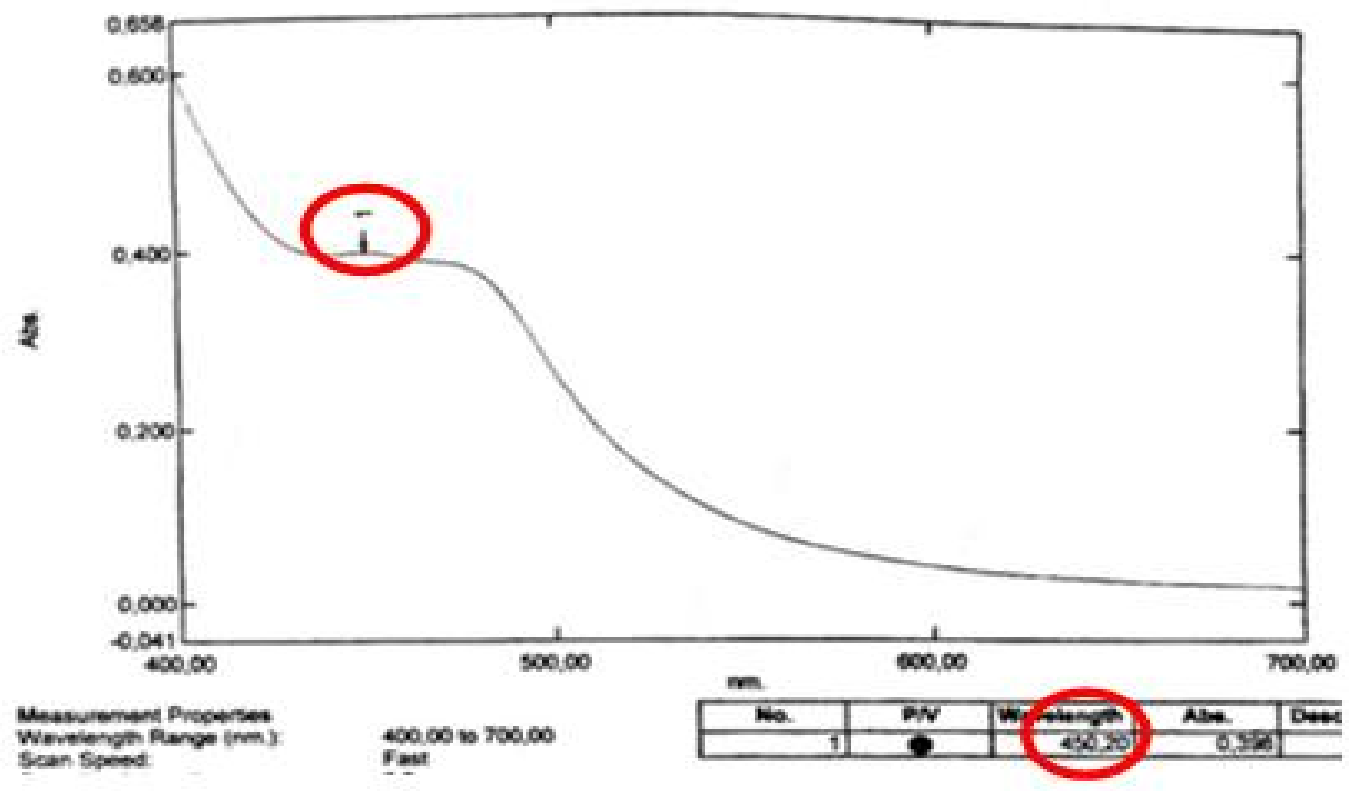


Gambar 6. Grafik Perbandingan Absorbansi Zat Warna Alami Secang pada Panjang Gelombang Maksimum

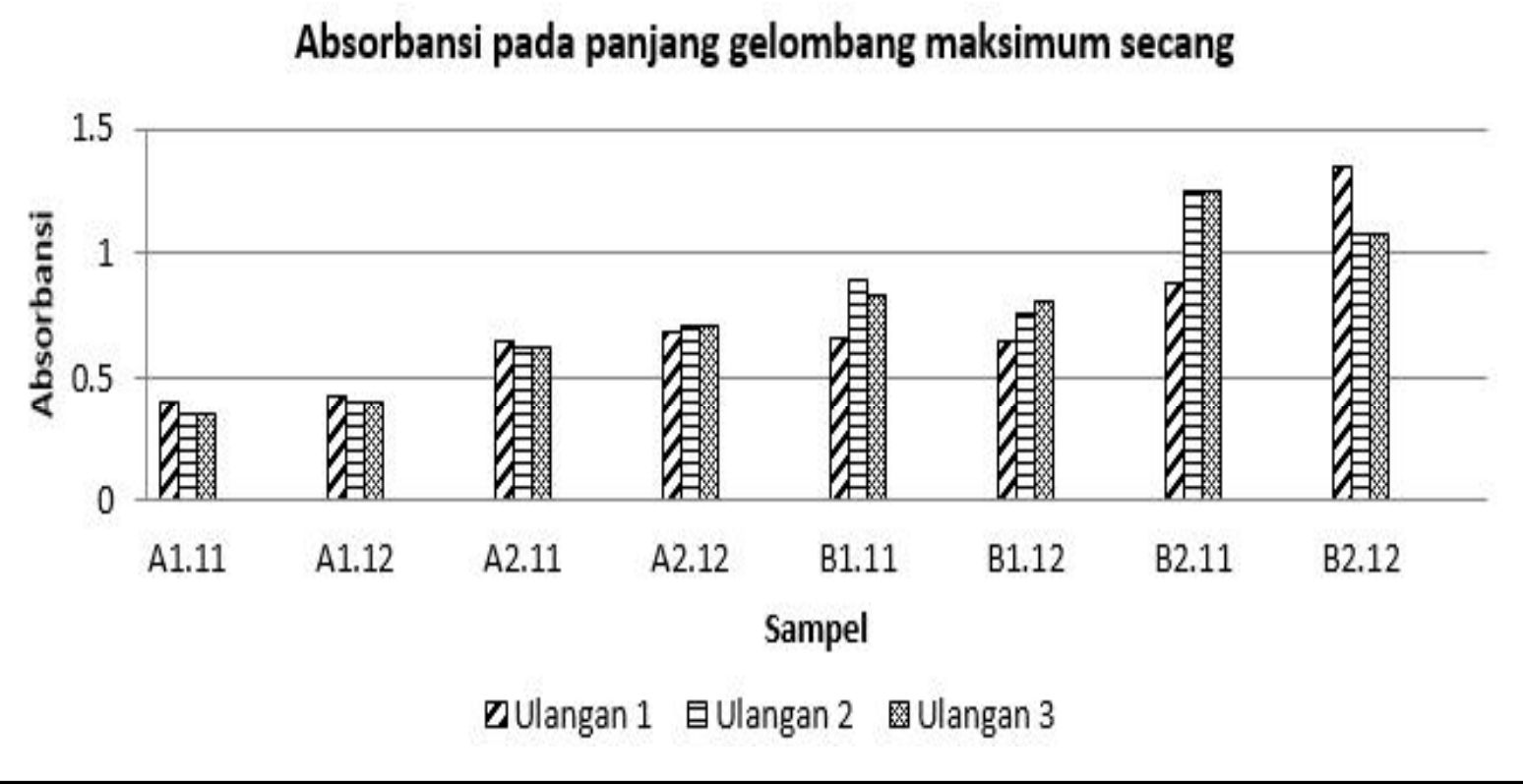

1 sebesar 0,35-0,428 dan cara ekstraksi 2 menunjukkan absorbansi yang lebih tinggi yaitu sebesar 0,619-0,709. Sementara itu, pewarna secang yang dibeli dari pasar menunjukkan absorbansi yang tidak konsisten. Hal tersebut karena secang yang dipasarkan yang telah mengalami distribusi dan penyimpanan terlalu lama sehingga zat-zat yang terkandung didalamnya telah mengalami penguapan.

Dari metode standarisasi yang menghasilkan warna merah secang konsisten, zat warna tersebut digunakan untuk mewarnai kain dengan cara dicelup. Kain yang digunakan adalah kain katun primisima. Sebelum kain dicelupkan pada pewarna alami, harus melalui proses mordanting terlebih dahulu. Proses mordanting dimaksudkan untuk meningkat-kan daya tarik zat warna alam terhadap bahan tekstil serta berguna untuk menghasilkan kerataan dan ketajaman warna yang baik. Proses mordanting dilakukan dengan mencelupkan kain pada larutan TRO (Tukey Red Oil) selama 1 jam. Setelah itu dilakukan proses pencelupan ke dalam pewarna alami secang. Proses pencelupan dilakukan selama 15 menit, kemudian dikeringkan dengan cara diangin-angin, baru dicelup lagi selama 15 menit lagi. Proses tersebut diulangi sebanyak tiga kali.

Warna yang dihasilkan dari metode standarisasi pada sampel A11, A21, A31, dan A41 dapat dilihat pada Gambar 7. Warna yang ditunjukkan pada Gambar 7 secara kasat masa tidak menunjukkan perbedaan yang signifikan. Selain itu, penilaian yang 
Gambar 7. Hasil Pencelupan Pewarna Secang Pada Kain Katun A11 (a), A21 (b), A31 (c), dan A41 (d)

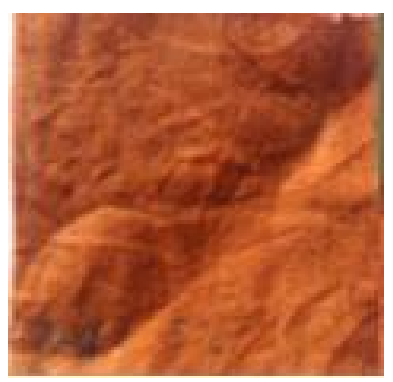

(a)

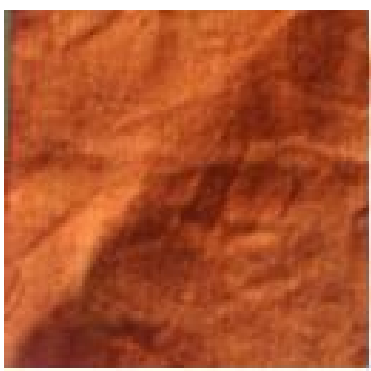

(b)

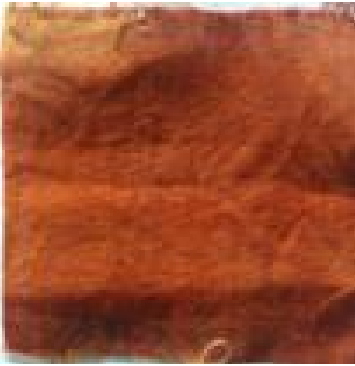

(c)

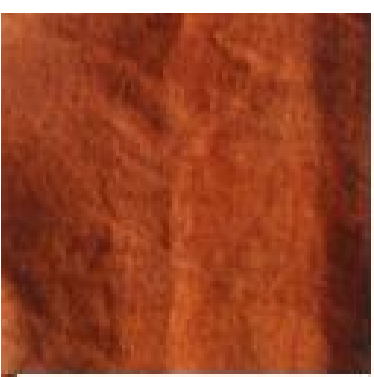

(d) konsisten dapat diacu dari hasil pembacaan spektrometer.

Gambar 8 merupakan desain batik yang digunakan pada aplikasi pewarnaan batik. Terdapat tiga jenis motif batik yang digunakan pada pewarnaan batik. Motif yang pertama adalah motif Parang Rusak. Motif parang rusak juga merupakan hadiah dari generasi ke generasi muda para bangsawan. Garis lurus diagonal pada batik parang rusak melambangkan rasa hormat, keteladanan serta ketaatan pada nilai-nilai kebenaran.
Parang rusak biasa digunakan prajurit setelah perang, untuk memberitahu raja bahwa mereka telah menang perang (Indriani, 2015). Motif yang kedua adalah tulisan kaligrafi UNY. Pada lambang universitas, kaligrafi UNY dibuat melingkar dengan tulisan Universitas Negeri Yogyakarta yang melambangkan globe dunia bersambung (uny.ac.id). Motif yang ketiga adalah struktur brazilin. Safitri (Rina \& Anshori, 2012) menyatakan bahwa salah satu komponen senyawa bioaktif yang terkandung dalam

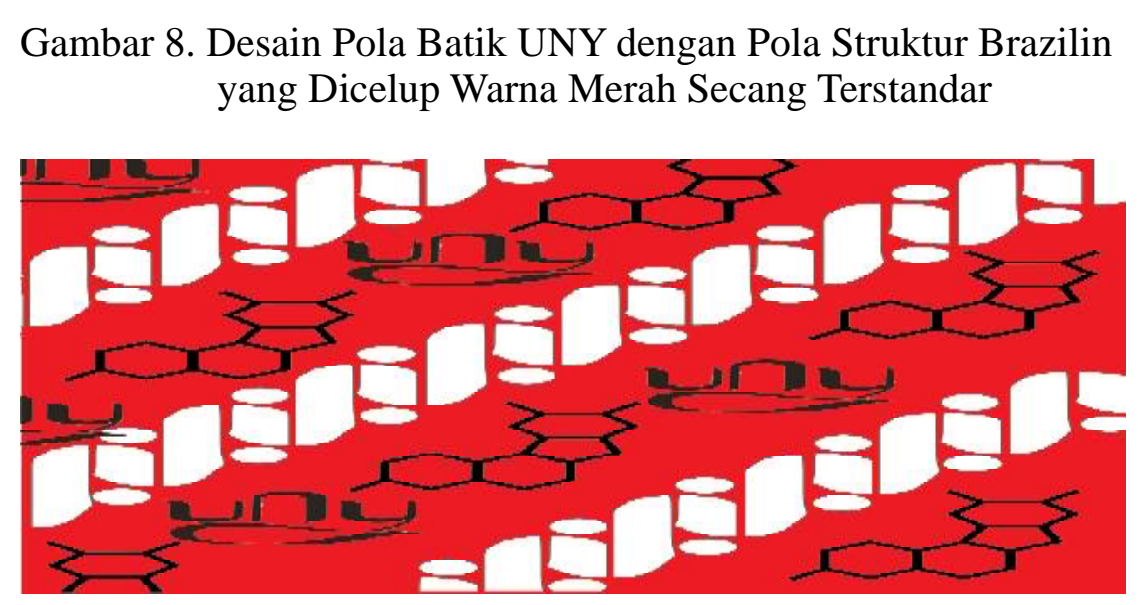


kayu secang yaitu brazilin. Struktur kimia brazilin disajikan pada Gambar 9.

Gambar 9. Struktur Kimia Brazilin
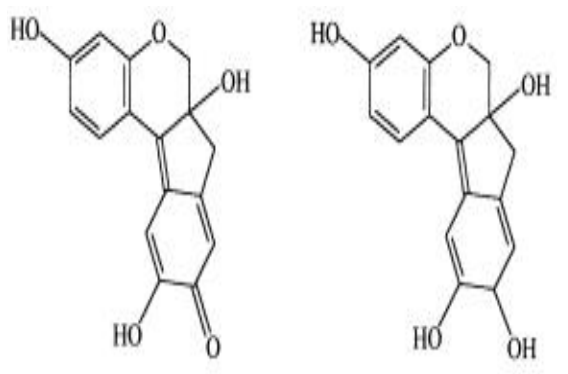

Brazilein

Bravilin

Penggunaan warna merah pada desain batik karena kayu secang dapat memberikan warna merah. Adanya komponen brazilin dalam kayu secang memberikan warna merah kecoklatan jika teroksidasi atau dalam suasana basa (Rina \& Anshori, 2012).

\section{SIMPULAN}

Proses standarisasi warna zat warna alami secang (Caesalpinia sappan L.) telah dapat dilakukan dengan metode spektroskopi UV-Vis dengan puncak serapan maksimum pada panjang gelombang 450,20 $\mathrm{nm}$. Sampel yang dapat meghasilkan warna merah alami secang yang konsisten adalah secang yang langsung diambil dari pohon dengan waktu maserasi minimal 1x24 jam dengan absorbansi sebesar 0,35-0,709.
Aplikasi pewarna merah secang telah dapat dilakukan dengan pola batik dasar Parang Rusak dengan variasi tulisan kaligrafi pada lambang UNY dan struktur kimia pewarna merah brazilin.

\section{DAFTAR PUSTAKA}

Amin, S., \& Yuliana, A. (2016). Analisis dan uji kestabilan zat warna kayu secang (Caesalpinia sappan L) menggunakan spektrofotometr UV-Vis dan inframerah. Jurnal Kesehatan Bakti Tunas Husada, 15(1).

Fardhyanti, D. S., \& Riski, R. D. (2015). Pemungutan brazilin dari kayu secang (Caesalpinia sappan L) dengan metode maserasi dan aplikasinya untuk pewarnaan kain. Jurnal Bahan Alam Terbarukan, 4(1).

Imam, G. (2003). Teori zat warna. Semarang: Badan Penerbit Universitas Diponegoro.

Indriani, L. (2015). Makna filosofi dan cerita di balik berbagai motif batik - seri Parang. Diunduh dari https:// museumbatik.com/.

Rina, O., \& Ansori, A. (2017). Efektivitas ekstrak kayu secang (Caesalpinia Sappan L.) sebagai bahan pengawet daging. Jurnal Penelitian Pertanian Terapan, 12(3), 181-186.

Winarti, C., \& Nurdjanah, N. (2005). Peluang tanaman rempah dan obat sebagai sumber pangan fungsional. $J$ Litbang Pertanian, 24(2), 47-55. 